\title{
Chemical cleaning of ultrafiltration membrane fouled by an activated sludge effluent
}

Nguyen, Sy; Roddick, Felicity

https://researchrepository.rmit.edu.au/esploro/outputs/9921858588501341/filesAndLinks?institution=61RMIT_INST\&index=null

Nguyen, S., \& Roddick, F. (2011). Chemical cleaning of ultrafiltration membrane fouled by an activated sludge effluent. Desalination and Water Treatment: Science and Engineering, 34(1-3), 94-99.

https://doi.org/10.5004/dwt.2011.2790

Document Version: Accepted Manuscript

Published Version: https://doi.org/10.5004/dwt.2011.2790

Repository homepage: https://researchrepository.rmit.edu.au

(C) 2011 Desalination Publications. All rights reserved

Downloaded On 2023/04/26 20:05:11 +1000 


\title{
Chemical cleaning of ultrafiltration membrane fouled by an activated sludge effluent
}

\author{
S.T. Nguyen and F.A. Roddick \\ School of Civil, Environmental and Chemical Engineering, RMIT University, GPO Box 2476, Melbourne, \\ Vic.3001, Australia \\ Tel.: +61 39925 2080; Fax: +61 39925 3746; E-mail: felicity.roddick@rmit.edu.au (F.A. Roddick).
}

\begin{abstract}
In this study, membrane foulants and cleaning efficiency of different membrane cleaners for the ultrafiltration (UF) of a municipal activated sludge effluent were investigated. The major membrane foulants were polysaccharides, proteins, and humic substances (HS). Backwashing the fouled membrane removed some polysaccharides and proteins, but was not able to displace the adsorbed HS. Of the cleaners studied for the polyvinylidene fluoride (PVDF) UF membrane the most effective were sodium hypochlorite (200 ppm available chlorine), Terg-a-zyme (1.0 wt.\%), and sodium dodecyl sulphate $(10 \mathrm{mM})$. The results indicated that hydrophobic attraction was the most important force keeping the hydraulically irreversible foulants attached to the membrane. The surfaces of the fouled and cleaned membranes were analysed and interactions among the membranes, foulants, and the cleaning agents were discussed in terms of their chemistry and cleaning efficiency.
\end{abstract}

Keywords Activated sludge effluent; chemical cleaning; cleaning efficiency, membrane foulant; ultrafiltration

\section{Introduction}

A municipal wastewater treatment plant in Victoria (Australia) has been investigating different methods to improve the quality of its product water. One of these is the addition of a low pressure membrane (LPM) filtration process to treat the secondary effluent generated from the activated sludge (AS) process.

Membrane fouling, which lowers the productivity of membrane processes, is unavoidable. Although periodic backwashing can significantly recover the flux by displacing some foulants, the accumulation of hydraulically irreversible foulants over long-term runs requires chemical cleaning of membranes to maintain their flux.

The efficiency of chemical cleaning depends on many factors, including chemical concentration, $\mathrm{pH}$, cleaning temperature, and cleaning time [1]. The mechanisms of flux recovery by different chemicals are complex and it has been recognised that the chemistry of foulants, membrane cleaners, and membrane materials may not be reliable factors for estimation of cleaning efficiency [2]. In practice, LPM filtration of secondary effluents is normally run with backwashing every $15-30 \mathrm{~min}$. [3]. Chemical cleaning is performed when backwashing cannot restore the flux to an acceptable level.

Predominant membrane foulants vary with wastewater sources and membrane characteristics. Many studies suggested that humic substances (HS) play a major role in causing membrane fouling [4, 5]. However, others found that polysaccharides and proteins were the major foulants in microfiltration and ultrafiltration of secondary effluents [3, 6]. Such variation and the dependence of chemical cleaning effectiveness on foulant chemistry illustrate the need for identifying the foulants for a particular wastewater and membrane type. 
The aim of this study was to investigate the ability of different membrane cleaning agents to restore the performance of the membrane used in UF of the AS effluent collected from the wastewater treatment plant. The membrane foulants were also identified, which provided insights to the differences in the cleaning efficiency of the chemicals.

\section{Materials and methods}

\subsection{Wastewater source}

A representative sample of the AS effluent from the wastewater treatment plant was transported to RMIT University and stored at $4^{\circ} \mathrm{C}$. Its characteristics are shown in Table 1.

Table 1. Characteristics of the AS effluent

\begin{tabular}{ll}
\hline Parameter & Value \\
\hline $\mathrm{pH}$ & 7.8 \\
DOC $\left(\mathrm{mg} \mathrm{L}^{-1}\right)$ & 13.3 \\
$\mathrm{UVA}_{254}\left(\mathrm{~cm}^{-1}\right)$ & 0.40 \\
\left.${\text { Specific UVA }\left(\mathrm{m}^{-1} \mathrm{mg}^{-1} \mathrm{~L}\right)}_{\text {True colour }\left(\mathrm{mg} \mathrm{Pt}^{-} \mathrm{Co} \mathrm{L}\right.}{ }^{-1}\right)$ & 3.02 \\
Turbidity (NTU) & 113 \\
\hline
\end{tabular}

\subsection{Analytical methods}

The $\mathrm{pH}$, conductivity, and turbidity were measured using a Mettler Toledo $\mathrm{pH}$ meter, a Hach Sension5 conductivity meter, and a Hach 2100P Turbidimeter, respectively. UV absorbance $\left(\mathrm{UVA}_{254}\right)$ was measured with a Unicam UV/vis spectrophotometer. A Hach spectrophotometer (model DR/4000) was used to determine the sample colour in Pt-Co units at a wavelength of $455 \mathrm{~nm}$ according to Standard Method 2120 C [7].

Sample apparent molecular weight distribution (AMWD) and dissolved organic carbon (DOC) concentration were determined using liquid chromatography with organic carbon detection (LC-OCD) at the University of New South Wales, Sydney, Australia. The instrument and procedure are described elsewhere [8].

Fourier transform infrared (FTIR) spectra of the virgin, fouled and cleaned membranes were collected using the attenuated total reflectance (ATR) method with a Spectrum 100 FT-IR spectrometer (Perkin Elmer). Scanning electron microscopy (SEM) images and energy dispersive X-ray (EDX) spectra of the membranes were obtained with a microscope (Quanta 200, FEI) equipped with an EDX detector.

\subsection{Filtration experiment set-up}

Filtration experiments were carried out using a stirred dead-end filtration cell (Amicon 8050, effective membrane area $13.4 \mathrm{~cm}^{2}$ ) with a polyvinylidene fluoride (PVDF) UF membrane (HFM-116, Koch Membrane Systems). This membrane has a nominal molecular weight cutoff of $50 \mathrm{kDa}$ and its pure water flux was approximately $150 \mathrm{~L} \mathrm{~m}^{-2} \mathrm{~h}^{-1} \mathrm{bar}^{-1}$. According to the manufacturer, it can be cleaned at $\mathrm{pH}$ 1.5-10.5. The membrane was hydrophobic since its (water) contact angle (measured with an OCA 20 contact angle meter (Data Physics, Germany) using the sessile drop method) was $58 \pm 2^{\circ}$ (i.e., $>50^{\circ}$ ).

Membrane filtration of the AS effluent was conducted at $110 \mathrm{kPa}$ (regulated using compressed nitrogen gas) and a stirrer speed of $80 \mathrm{rpm}$. The filtrate mass was recorded using a top-loading electronic balance (Explorer, Ohaus, accuracy \pm 0.01 g). Prior to filtration, 200 $\mathrm{mL}$ Milli-Q water was passed through each membrane to remove preservatives and determine 
the pure water flux $\left(\mathrm{J}_{0}\right)$. Filtration with the AS effluent was stopped when permeate volume reached $150 \mathrm{~L} \mathrm{~m}^{-2}$ (approximately $150 \mathrm{~min}$.), after which membrane cleaning was carried out.

\subsection{Membrane cleaners}

The cleaning agents used in this study were of analytical or technical grade and were made up in Milli-Q water (Table 2). The cleaner concentrations were selected so that the allowable $\mathrm{pH}$ range and chlorine tolerance of the membrane were not exceeded.

Table 2. The membrane cleaners investigated

\begin{tabular}{|c|c|c|c|}
\hline Chemical & Supplier & Concentration & $\mathrm{pH}$ \\
\hline Sodium hydroxide $(\mathrm{NaOH})$ & Merck & $0.3 \mathrm{mM}$ & 10.5 \\
\hline Hydrochloric acid (HCl) & $\mathrm{BDH}$ & $10 \mathrm{mM}$ & 2.0 \\
\hline Hydrogen peroxide $\left(\mathrm{H}_{2} \mathrm{O}_{2}\right)$ & Ajax Finechem & $1.0 \mathrm{wt} . \%$ & 4.5 \\
\hline $\mathrm{H}_{2} \mathrm{O}_{2} / \mathrm{NaOH}$ mixture $\mathrm{pH} 10.5$ & - & 1.0 wt. $\% \mathrm{H}_{2} \mathrm{O}_{2}$ & 10.5 \\
\hline $\begin{array}{l}\text { Disodium ethylenediaminetetraacetic acid } \\
\left(\mathrm{Na}_{2} \text { EDTA) }\right.\end{array}$ & $\mathrm{BDH}$ & $1.0 \mathrm{mM}$ & 4.8 \\
\hline Tetrasodium EDTA ( $\mathrm{Na}_{4}$ EDTA) & Ajax Finechem & $0.4 \mathrm{mM}$ & 10.5 \\
\hline Sodium hypochlorite (NaOCl) & Ajax Finechem & 200 ppm as chlorine & $10.5^{*}$ \\
\hline Sodium dodecyl sulphate (SDS) & $\mathrm{BDH}$ & $10 \mathrm{mM}$ & 6.8 \\
\hline Terg-a-zyme & Sigma-Aldrich & $1.0 \mathrm{wt} . \%$ & 9.6 \\
\hline
\end{tabular}

*Adjusted with a small amount of $\mathrm{HCl}$

\subsection{Membrane cleaning procedure}

The fouled membranes were backwashed by placing them upside down in the filtration cell and filtering the permeate at $110 \mathrm{kPa}$ for $5 \mathrm{~min}$. They were then returned to their processing orientation and the pure water flux was measured. The backwashed membranes were then soaked with gentle shaking in solutions of the cleaning agents at $24^{\circ} \mathrm{C}$ for $45 \mathrm{~min}$. The pure water flux of the chemically cleaned membranes was determined after rinsing them thoroughly with Milli-Q water. The effectiveness of chemical cleaning was evaluated using the cleaning efficiency $\left(\mathrm{E}_{\mathrm{RW}}\right)$ and pure water flux recovery (WRF, defined as the ratio of the pure water flux of the cleaned membranes $\left(\mathrm{J}_{\mathrm{c}}\right)$ to that of the virgin membrane $\left.\left(\mathrm{J}_{0}\right)\right)[1]$.

To identify the foulants removed by backwashing, a fouled membrane was backwashed with Milli-Q water for 5 min. and the backwash effluent (after filtration through a $0.45 \mu \mathrm{m}$ cellulose acetate membrane) was subjected to LC-OCD analysis.

\section{Results and discussion}

3.1. Membrane foulants in UF of the AS effluent

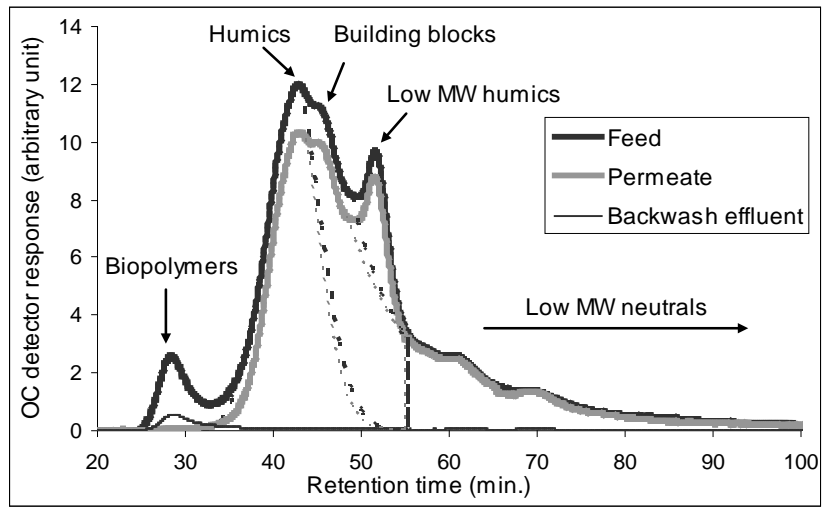

Fig. 1. AMWDs of the AS effluent and the permeates 
The LC-OCD chromatograms of the feed and the permeate (Fig. 1) show that biopolymers (MW $>>20,000 \mathrm{Da}$ ), which included polysaccharides and proteins, and humic substances (HS, MW=1,000-20,000 Da), were the compounds most significantly retained by the membranes. HS was probably retained by hydrophobic interaction with the hydrophobic membrane [6, 9]. The rejection of HS was associated with the removal of true colour by the membrane (feed colour $=113$ Pt-Co units, permeate colour $=67$ Pt-Co units). Some building blocks (MW=300-500 Da) were also rejected by the membrane, which was likely to occur after the pores were blocked with biopolymers and HS. Consequently, it was concluded that polysaccharides, proteins, and HS were the major membrane foulants. This was further confirmed by the results obtained from ATR-FTIR analysis (Fig. 2).

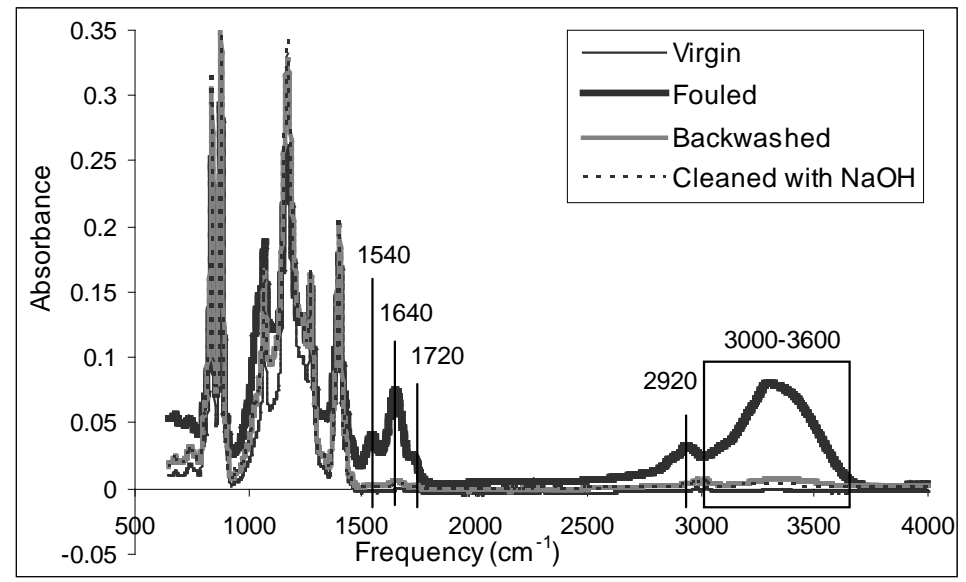

Fig. 2. FTIR spectra of the virgin, fouled, and cleaned membranes

Fig. 2 shows that the foulants had a peak at $1540 \mathrm{~cm}^{-1}$, indicating the existence of $\mathrm{N}-\mathrm{H}$ bonds and $\mathrm{C}=\mathrm{N}$ stretching of secondary amides in the foulant layer. The peak at $1640 \mathrm{~cm}^{-1}$ corresponded to stretching vibration of $\mathrm{C}=\mathrm{O}$ bonds connected to primary amides of proteins. The peaks around $1720 \mathrm{~cm}^{-1}$ and $2920 \mathrm{~cm}^{-1}$ were attributed to stretching vibrations of carboxyl groups and aliphatic $\mathrm{C}-\mathrm{H}$ stretching, respectively. The broad rounded band around $3000-3650 \mathrm{~cm}^{-1}$ was due to $\mathrm{O}-\mathrm{H}$ stretching of hydroxyl groups in polysaccharides $[6,10]$.

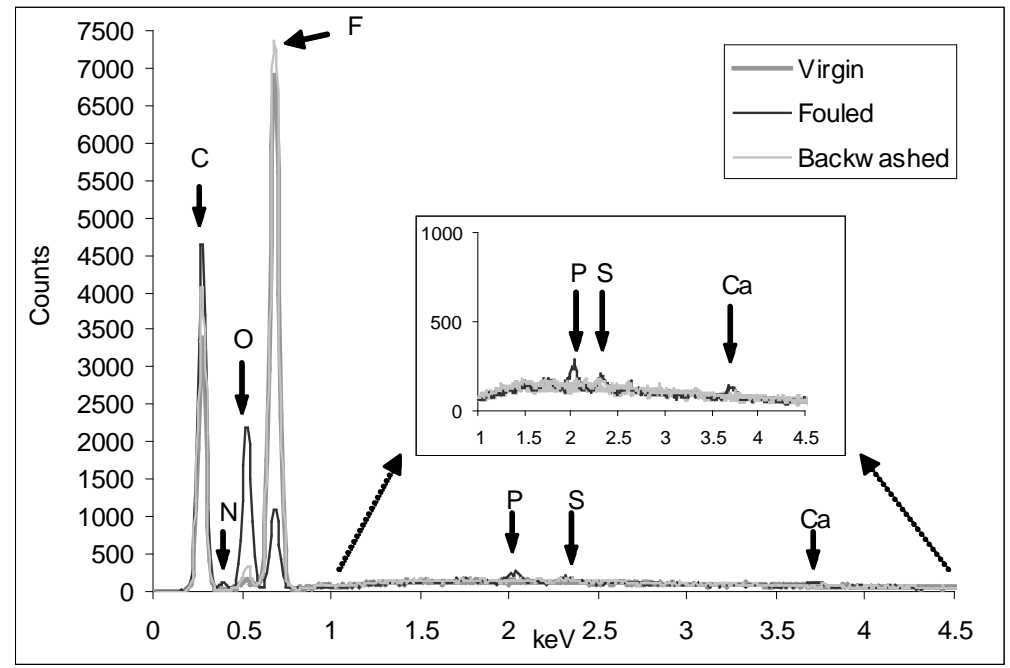

Fig. 3. EDX spectra of the virgin, fouled, and backwashed membranes

The EDX spectrum of the virgin membrane (Fig. 3) indicated the presence of carbon, oxygen, and fluorine. The presence of the foulants on the membrane resulted in an increase in the 
oxygen peak, a large reduction in the fluorine peak, and the appearance of the nitrogen, phosphorus, and sulphur peaks. These changes were attributed to the presence of polysaccharides, proteins, and HS in the fouling layer. A trace amount of calcium was also detected, indicating that calcium may have played a role in causing membrane fouling. Calcium ion has been found to contribute to membrane fouling in UF by promoting the aggregation of organic molecules in solution via the formation of calcium bridges between the carboxylic groups of HS [11]. This is further discussed in section 3.3.

\subsection{Removal of foulants by backwashing}

The LC-OCD chromatogram of the backwash effluent (Fig. 2) shows that backwashing removed some proteins and polysaccharides retained by the membrane, which could be attributed to these high MW compounds being larger than the membrane pores and forming a cake layer on the membrane surface. However, backwashing was not effective in displacing HS from the membrane. This suggests that HS adhered to the membrane surface and/or pore walls through strong hydrophobic attraction (both the membrane and HS were hydrophobic).

\subsection{Cleaning efficiencies $\left(E_{R W}\right)$ of different chemicals}

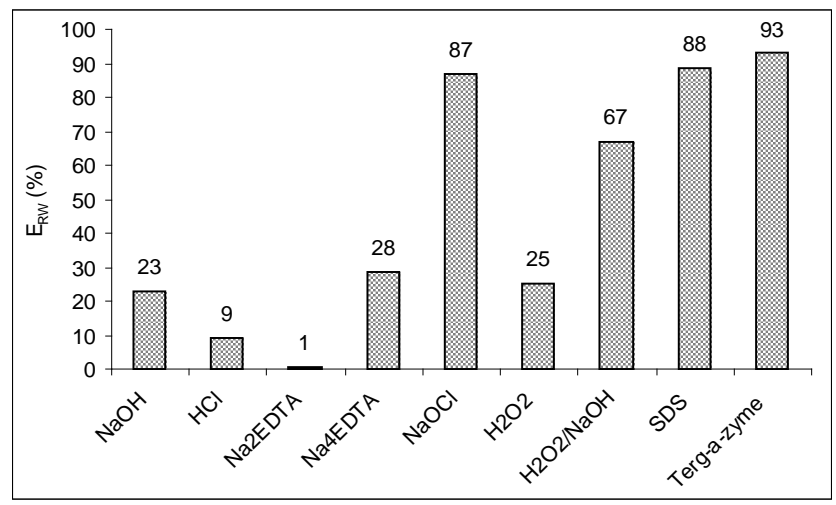

Fig. 4. Cleaning efficiencies of different membrane cleaners

The $E_{\mathrm{RW}}$ values of the chemicals are shown in Fig. 4. The $\mathrm{E}_{\mathrm{RW}}$ of $\mathrm{NaOH}$ was low, indicating that its hydrolysis effect (on polysaccharides and proteins) and solubilisation effect (on HS) [9] was not sufficient for effective foulant removal. $\mathrm{HCl}$ gave an $\mathrm{E}_{\mathrm{RW}}$ of $9 \%$ which was attributed to the mild oxidation of some proteins and polysaccharides [9].

Of the two chelating agents, $\mathrm{Na}_{4}$ EDTA was more effective than $\mathrm{Na}_{2}$ EDTA in restoring the membrane flux. This was because the solution of $\mathrm{Na}_{4}$ EDTA was alkaline ( $\mathrm{pH}$ 10.5), which encouraged the dissolution of the foulants. The solution of $\mathrm{Na}_{2}$ EDTA was moderately acidic ( $\mathrm{pH}$ 4.8) and had virtually no flux restoring effect as the moderately acidic medium did not favour foulant dissolution [9]. The $\mathrm{Na}_{4} \mathrm{EDTA}$ had a higher $\mathrm{E}_{\mathrm{RW}}$ than $\mathrm{NaOH}$ (both at $\mathrm{pH}$ 10.5), which indicated that some of the HS remaining on the membrane after backwashing was probably in the form of humic-calcium complexes and $\mathrm{Na}_{4}$ EDTA recovered the membrane flux by simultaneously removing calcium from these complexes (through ligand exchange) [12] and dissolving the foulants. The foulant dissolution effect of hydroxide ions appeared to be much more important as $\mathrm{Na}_{2}$ EDTA was ineffective in restoring the membrane flux.

$\mathrm{NaOCl}$ and $\mathrm{H}_{2} \mathrm{O}_{2}$ are both oxidising agents which are believed to remove membrane foulants by oxidation reactions [1, 2, 9]. Oxidation breaks down functional groups of organic foulants to carboxyl, ketonic, and aldehyde groups, making the foulants more susceptible to hydrolysis at high $\mathrm{pH}$. As a result of these reactions, the foulants become water soluble and detach from the membrane. In this study $\mathrm{H}_{2} \mathrm{O}_{2}$ gave a much lower $\mathrm{E}_{\mathrm{RW}}$ than $\mathrm{NaOCl}$, although its 
concentration $(10,000 \mathrm{ppm}$ or $294 \mathrm{mM})$ was much higher than that of $\mathrm{NaOCl}(200 \mathrm{ppm}$ chlorine or $5.6 \mathrm{mM}$ ). Because the $\mathrm{E}_{\mathrm{RW}}$ of the $\mathrm{H}_{2} \mathrm{O}_{2} / \mathrm{NaOH}$ mixture (pH 10.5) was higher than the $\mathrm{E}_{\mathrm{RW}}$ of $\mathrm{H}_{2} \mathrm{O}_{2}$ and $\mathrm{NaOH}$ (Fig. 4), part of the reason for the low $\mathrm{E}_{\mathrm{RW}}$ of the $\mathrm{H}_{2} \mathrm{O}_{2}$ was the acidic $\mathrm{pH}$ of this chemical. Chlorine may also have caused swelling of membranes, which increased the mass transfer of the cleaning agent to the membrane surface [13], resulting in a higher $E_{R W}$ for $\mathrm{NaOCl}$. Membrane cleaning with $\mathrm{NaOCl}$ and $\mathrm{H}_{2} \mathrm{O}_{2}$ was also conducted at $40^{\circ} \mathrm{C}$ and the $\mathrm{E}_{\mathrm{RW}}$ of $\mathrm{NaOCl}$ and $\mathrm{H}_{2} \mathrm{O}_{2}$ at this temperature was $98 \%$ and $77 \%$, respectively. Thus the higher temperature improved cleaning efficiency and $\mathrm{NaOCl}$ was a better cleaning agent overall. On the other hand, Arnal et al. [14] found that $\mathrm{NaOCl}$ performed better than $\mathrm{H}_{2} \mathrm{O}_{2}$ at $25^{\circ} \mathrm{C}$, but the reverse happened at $40^{\circ} \mathrm{C}$ in cleaning a polysulfone UF membrane fouled by a surface water. It should be noted that although the oxidative power of $\mathrm{H}_{2} \mathrm{O}_{2}$ is typically greater than that of $\mathrm{OCl}^{-}$, exceptions have been observed, depending on the characteristics of the solution and the compounds to be oxidised [15].

SDS and Terg-a-zyme were the two most effective cleaning agents. The high $\mathrm{E}_{\mathrm{RW}}$ of SDS confirmed that hydrophobic attraction was the major force keeping the hydraulically irreversible foulants and the hydrophobic membrane together. It is generally understood that during membrane cleaning with SDS, the hydrophobic tails of the surfactant molecules adsorb to the foulant molecules and their hydrophilic heads are orientated towards the aqueous phase [16]. This reduces the hydrophobicity of the foulants and they are solubilised into the aqueous phase. At SDS concentrations higher than the critical micelle concentration (8.36 $\mathrm{mM}$ in deionised water), as in this study, micelles also form in the cleaning solution. These micelles diffuse into the fouling layer, dissociate and adsorb as monomers on the foulant molecules and enhance foulant solubilisation [17].

Terg-a-zyme is a blend of the anionic surfactant sodium dodecyl benzene sulphonate and a protease enzyme. The higher $\mathrm{E}_{\mathrm{RW}}$ of Terg-a-zyme than SDS may be due to the higher $\mathrm{pH}$ and/or the surfactant and the enzyme acting together to solubilise the foulants. The enzyme may have broken down some of the protein foulants, making them soluble in the cleaning solution and/or more readily solubilised by the surfactant.

From economic and practical viewpoints, $\mathrm{NaOCl}$ is superior to SDS and Terg-a-zyme since it is less expensive and does not create foams like the other two. However, the use of SDS or Terg-a-zyme may reduce the risk of membrane degradation caused by $\mathrm{NaOCl}$ in long-term use.

Three fouling and cleaning cycles were also conducted with the three most effective cleaners and accumulation of residual fouling was observed (Fig. 5).

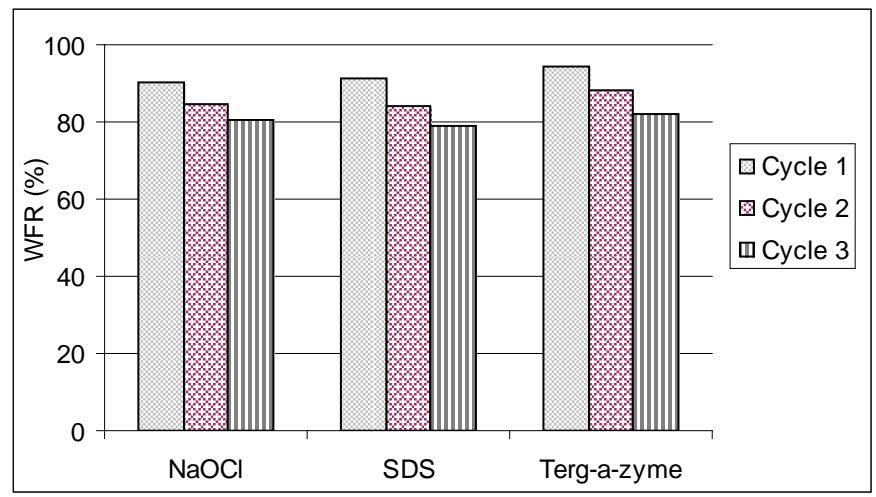

Fig. 5. Changes in WFR of NaOCl, SDS, and Terg-a-zyme over three UF cycles 
Although this did not appear to reduce the permeate flux in UF of the AS effluent in the first three filtration cycles (data not shown), it can be inferred that such a reduction in the permeate flux would occur in long-term operation and therefore cleaning-in-place (CIP) with longer soaking time and/or higher cleaning agent concentrations would be needed. Elevated temperature (within manufacturer's specifications) may also be used to increase the cleaning efficiency and reduce the cleaning time. The rejections of DOC, $\mathrm{UVA}_{254}$, and colour of the virgin membranes and the treated membranes were comparable, indicating that high flux recoveries were not associated with degradation of the membranes.

\subsection{Membrane cleanliness shown by FTIR spectroscopy and SEM/EDX}

Backwashing removed most of the foulants on the membrane surface, leaving only traces of polysaccharides and proteins (Fig. 2, peaks at $1640 \mathrm{~cm}^{-1}$ and $3000-3650 \mathrm{~cm}^{-1}$ ). The FTIR spectrum of the membrane cleaned with $\mathrm{Na}_{2}$ EDTA (not shown for clarity of Fig. 2) was similar to that of the backwashed membrane, while the FTIR spectra of the membranes cleaned with the other chemicals were very similar to the spectrum of the virgin membrane. The results indicate that FTIR spectroscopy could detect organic foulants on the membrane surface but could not differentiate the membranes after the removal of these foulants.

SEM images of the virgin, fouled and cleaned membranes were collected. The surface of the fouled membrane was covered with the foulant layer, which made the pores invisible. After backwashing, the pores became visible, together with some remaining trace foulants. The SEM images of all the chemically cleaned membranes were very similar to that of the virgin membrane. SEM therefore did not allow differentiation of the membranes treated with the different cleaning agents.

The EDX spectrum of the backwashed membrane had a higher oxygen peak compared with the virgin membrane (Fig. 3) due to the presence of organic foulants remaining after backwashing. The EDX spectrum of the membranes cleaned with $\mathrm{Na}_{2}$ EDTA was similar to that of the backwashed membrane. The EDX spectra of the membranes cleaned with the other chemicals were very similar to the spectrum of the virgin membrane and therefore the technique was not able to differentiate the degree of cleanliness of these membranes.

\section{Conclusions}

Fouling and cleaning of the PVDF membrane used for UF of AS effluent was investigated. The membrane foulants were identified as polysaccharides, proteins, and HS. Hydraulic backwashing removed some of the polysaccharides and proteins retained on the membrane, but was ineffective for removing HS. The alkaline cleaners were much more efficient than the acidic cleaners for removing the hydraulically irreversible foulants. The most effective cleaning agents were $\mathrm{NaOCl}$, SDS, and Terg-a-zyme, with cleaning efficiencies greater than 85\%. Accumulation of residual fouling after chemical cleaning was observed. Membrane cleanliness was assessed using a combination of flux measurement (cleaning efficiency) and surface analyses (FTIR spectroscopy, SEM/EDX), the former being a more reliable indicator.

\section{Acknowledgement}

The authors wish to acknowledge the Australian Research Council (ARC) for financially supporting this research (project number LP0776870).

\section{References}

[1] N. Porcelli and S. Judd, Chemical cleaning of potable water membranes: A review, Sep. Purif. Technol., 71 (2010) 137-143. 
[2] A. Al-Amoudi and R.W. Lovitt, Fouling strategies and the cleaning system of the NF membranes and factors affecting cleaning efficiency, J. Memb. Sci., 303 (2007) 4-28.

[3] C. Laabs, G. Amy, M. Jekel, Understanding the size and character of fouling-causing substances from effluent organic matter (EfOM) in low-pressure filtration, Environ. Sci. Technol., 40 (2006) 4495-4499.

[4] C. Combe, E. Molis, P. Lucas, R. Riley, M. Clark, The effect of CA membrane properties on adsorptive fouling by humic acid, J. Memb. Sci. 154 (1999) 73-87.

[5] W. Yuan and A.L. Zydney, Humic acid fouling in ultrafiltration, Environ. Sci. Technol., 34 (2000) 5043-5050.

[6] C. Jarusutthirak, G. Amy, J-P. Croué, Fouling characteristics of wastewater effluent organic matter (EfOM) isolates on NF and UF membranes, Desalination, 145 (2002) 247255.

[7] Standard Methods for the Examination of Water \& Wastewater, twenty-first ed., American Public Health Association (APHA), Washington DC, 2005.

[8] S. Liu, M. Lim, R. Fabris, C.W.K. Chow, M. Drikas, G. Korshin, R. Amal, Multiwavelength spectroscopic and chromatography study on the photocatalytic oxidation of natural organic matter, Water Res., 44 (2010) 2525-2532.

[9] C. Liu, S. Caothien, J. Hayes, T. Caothuy, T. Otoyo, T. Ogawa, Membrane chemical cleaning: from art to science, in: Proceedings of the AWWA Water Quality Technology Conference, March 4-7, 2001, San Antonio, Texas, USA.

[10] K.J. Howe, K.P. Ishida, M.M. Clark, Use of ATR/FTIR spectrometry to study fouling of microfiltration membranes by natural waters, Desalination, 147 (2002) 251-255.

[11] W-Y. Ahn, A.G. Kalinichev, M.M. Clark, Effects of background cations on the fouling of polyethersulfone membranes by natural organic matter: Experimental and molecular modelling study, J. Memb. Sci., 309 (2008) 128-140.

[12] S. Hong and M. Elimelech, Chemical and physical aspects of natural organic matter (NOM) fouling of nanofiltration membranes, J. Memb. Sci., 132 (1997) 159-181.

[13] L.J. Zeman and A.L. Zydney, Microfiltration and Ultrafiltration: Principles and Applications, Marcel Dekker, New York, 1996.

[14] J.M. Arnal, B. Garcia-Fayos, M. Sancho, G. Verdu, Ultrafiltration membrane cleaning with different chemical solutions after treating surface water, Desalination and Water Treatment, 7 (2009) 198-205.

[15] J.C. Crittenden, R.R. Trussell, D.W. Hand, K.J. Howe, G. Tchobanoglous (eds), Water Treatment Principles and Design, John Wiley and Sons, USA, 2006.

[16] H. Gecol, Chapter 2: The basic theory, in R. Farn (ed), Chemistry and technology of surfactants, Blackwell Publishing, USA, 2006, pp. 24-45.

[17] Q. Li and M. Elimelech, Organic fouling and chemical cleaning of nanofiltration membranes: measurements and mechanisms, Environ. Sci. Technol., 38 (2004) 46834693. 